\title{
Accounting Education in the Universities and Structuring According to the Expectations of the Business World
}

\author{
Nurkhodzha Akbulaev ${ }^{*}$, Ilkin Mammadov, Samir Shahbazli \\ Department of Economics and Business Administration, Azerbaijan State University of Economics (UNEC), Azerbaijan
}

Received October 4, 2020; Revised February 5, 2021; Accepted February 20, 2021

\section{Cite This Paper in the following Citation Styles}

(a): [1] Nurkhodzha Akbulaev, Ilkin Mammadov, Samir Shahbazli , "Accounting Education in the Universities and Structuring According to the Expectations of the Business World," Universal Journal of Accounting and Finance, Vol. 9, No. 1, pp. 130-137, 2021. DOI: 10.13189/ujaf.2021.090114.

(b): Nurkhodzha Akbulaev, Ilkin Mammadov, Samir Shahbazli (2021). Accounting Education in the Universities and Structuring According to the Expectations of the Business World. Universal Journal of Accounting and Finance, 9(1), 130-137. DOI: 10.13189/ujaf.2021.090114.

Copyright@2021 by authors, all rights reserved. Authors agree that this article remains permanently open access under the terms of the Creative Commons Attribution License 4.0 International License

\begin{abstract}
One of the important factors shaping accounting education is the business world. Structuring of accounting education according to the expectations of the business world which will employ the graduates is an important issue and it is especially necessary in our country. Every year, significant numbers of expenditures are provided for education in Azerbaijan. In order to get even more efficiency from these expenditures, education system should be developed, updated and renewed. Developed countries meet the need for labor force by the business world with vocational training methods which are formed according to businesses' internal dynamics, by taking advantage of international experiences. Countries that implement their education based on university-business cooperation are only those who apply school-based education, and countries that adopt both approaches but are constantly in pursuit of achieving this goal through three different methods. (It needs to indicate the methods) The current education system in Azerbaijan is based on theoretical approach. Due to the expectations of the business world and the importance of modern accounting education, the specialization level of the graduates is expected to be brought to the standards of the business world who will employ them, by restructuring accounting education itself. In this study, we analyzed expectations of the business world from the accounting education in the Universities and Vocational
\end{abstract}

Schools in Azerbaijan and determined main problems they face in this field. For this purpose, a research has been conducted on the expectations of the companies operating in Baku from teaching of accounting. In this research, general information about accounting and educational institutions, the structure of the current accounting training in universities, the perspective of the business world in accounting teaching and their expectations were analyzed. In the technical part, 110 questionnaires collected from various respondents were analyzed with SPSS-25 program package with descriptive statistics and factor analysis methods and the results were interpreted. The vocational courses taken by new graduates during their accounting education are ranked according to their importance by the members of the profession.

Keywords University, Accounting Training, Reconfiguration of Accounting Training, Business World

\section{Introduction}

Pursuing and adjusting fast development trends in today's world is one of the main topics in all sectors. Technological advancement takes an important place in accounting as well as all spheres. While people used to 
create a record, register and prepare fundamental financial statements previously, in today's world all above-mentioned processes are realized by technology but with human support yet.

Pursuing improvements in today's world and giving trainings according to those improvements in accounting field is one of the duties of all universities. It is required to meet with demands of business world correctly and appropriately. If accounting training provided by universities is not timely and appropriate to market conditions, reliance and attitude of business world to the university will change. At the same time, graduates' difficulties such as seeking a job will come into question. In case timely accounting training is not presented by universities, great deal of course-type certificate programs will serve to the business world more properly.

In this study, accounting concept, accounting system, training notion, accounting training and obstacles encountered in accounting training have been addressed in theoretical framework. In implementation part, survey application has been implemented to business world and obtained findings have been interpreted by SPSS package analysis.

\section{Literature Review}

In this part of the study, the main studies on accounting education in vocational schools and evaluating the expectations of the members of the profession from the graduates are presented.

Yildiz (2017), in a study conducted by the Independent Accountant Financial Advisors in Kayseri to determine the expectations of the graduates of the Vocational School of Accounting Department and the professional competencies of the graduates, found that the education and training given in Vocational High Schools were generally insufficient and that applied training should be given priority. It has been determined that Independent Accountant financial advisors want their graduates to be reliable, loving, hardworking and responsible, open to innovation and learning rather than work experience.

Yurekli and Gönen (2015), in their study using a semi-structured interview technique, revealed that the increasing number of students due to pass without an exam, the need for sufficient classrooms and equipment, and lack of instructors are a problem. They concluded that theory and practice should be given together.

Alkan (2015) found in his study to investigate the expectations of enterprises in Izmir from associate degree education, that regional requirements are not reflected in the educational contents of the universities examined.

Tugay and Ömürbek (2014) determined that there are differences between the expectations of the members of the profession and the education provided in the study, in which they evaluated the application level of accounting education in Vocational Colleges in Burdur province and whether the education provided is sufficient in practice.

Apostolou et al. (2019) examined 101 articles published in five journals in 2018 for the studies on accounting education. They updated their previous 13 accounting education literature reviews by organizing and summarizing their contributions to the accounting education iterator in 2018. The articles are divided into five sections corresponding to traditional knowledge bases. These departments consist of curriculum and instruction, education according to content area, educational technology, students, and faculty. In addition, the research rigor of empirical articles was discussed and criticized.

Wells (2018) investigated the selection of five textbooks used by eight university professors operating in New Zealand for a preparatory introduction to accounting course. For those who plan to write or update each textbook briefly, two suggestions are presented: (a) clearly state how the accounting system is integrated with the business information system and (b) better reflect how technology is used in accounting practice.

Amine Khayati (2020) investigated the perceptions of business students about the importance of faculty characteristics classified according to teaching, experience, research, service, and degree connection. There are policy implications of educational institutions in at least three areas in their findings on the accreditation process, curriculum design, and teaching evaluation and promotion.

\section{Accounting Training}

Teaching and learning accounting should be arranged to be compatible with the difficulties of new accounting role. Universities are looking for various strategies to teach vocational accounting competencies currently being required in accounting profession (Zraa, 2011:2).

Weil and Calhoun (2009) in order to evaluate which teaching and learning model will be the most appropriate in future accountants' training. Findings show that social solidarity theory and peer learning model are the most appropriate test for accounting training in a new millennium.

Accountants need intellectual abilities such as problem-solving and critical thinking. Intellectual abilities include associating obtained concepts with new situations, thinking of yourself, critical evaluation of new data and situations and knowledge application from one workplace context or problem to another one. Kavanagh and others (2009) have defined problem-solving as applicability of theory to practice, at the same time, critical analysis and thinking ability. Mohamed and Lashine (2003) have identified critical thinking as attainment ability to verifiable results to the questions which are not answered assertively and where all related information is not available. Intellectual abilities help accountants to do those 
below: a) to make judgements based on understanding of out-of-focus concept set; b) to implement ability demonstration and value-based reasoning for inductive thinking process (Awayiga, Onumah and Tsamenyi 2010).

Communication skills are fundamental for accountants' success and it is observed that it has a vital importance in meeting necessities of workplace (Kavanagh and peers, 2009). Communication skills are related to easy data transcription and obtainment (Andersen 1989; Awayiga, Onumah and Tsamenyi 2010; Ballantine and Larres 2009; Hancock and others 2009). Additionally, communication skills include effective listening for knowledge acquisition, understanding counterpart viewpoints and oral and written presentation of ideas and ability to argue and interview with others (Fortin and Legault 2010; Hancock vd. 2009; Jonesm G. and Abraham 2008; Rebele 1985).

\section{Challenges of Accounting Training}

A great deal of studies analyzing progress of accounting graduates exist. Stoner and Milner (2010) have indicated the necessity of life-long learning and close collaboration of accounting trainers with various partners in order to be graduated to successful career. Typically, while these studies prepare students to work in accounting field, it also shows that there are great changes in accounting teaching and learning (Accounting Training Change Commission 1990; Albrecht \& Sck 2000; Anderson 1989). Howeison (2003), proposed that new millennium will bring more changes in accounting practice to meet modifications affecting future direction of accounting training in accounting field (Zraa, 2011:7).

As existing training models are no longer considered sufficient, universities are actively in search of timely and modern strategies to teach and improve accounting competencies. Training models emphasizing memory and reminding the truth is accepted as a less desired approach in the course of accounting training and may lead to passive students (Jakling 2005). Kavanagh and Drennan (2007) state that existing teaching models put very little emphasis on improving students' vocational accounting competencies. Universally, accountants' education and training have been subjected to arguments (Mohamed and Lashine 2003). Albrecht and Sack (2000) emphasise the significance of ability improvement throughout accounting programs. Accounting trainers need to handle expected changes in accountants' abilities by improving more interdisciplinary and analytical lessons and education models in their instructions (Howieson 2003). Suggested strategies to eliminate determined deficiencies have focused on expanding curriculum and improving alternative presentation strategies.

Some researches conducted in accounting training put emphasis on the importance of teaching problem-solving and group skills to accounting students. For instance,
Hodson (1988) defended the necessity of defining and solving unstructured problems for students by using wide variety of knowledge sources as it is a basic requirement in work environment. Farrell and Farell (2008) have stated that teamwork about university issue is a sturdy preparation for workplace participation. Zakaria and Iksan (2007) defend that it is necessary to work as a group since accounting students need these abilities in business environment. Mohid and others (2009) have stated that accounting students improve attendance, self-confidence and leadership skills better by working with groups. Vast majority of employees does not expect their employees to line up and compete with the colleagues without direct interaction with them (Johnson \& Johnson 1994). Therefore, accounting training should provide students' improvement of required communication skills and business sense (Albrecht and Sack 2000; Jones, G. and Abraham 2008).

\section{Importance of Research}

In Today's world, universities need to make collaboration with industry in order to be the fourth-generation university. There is a need for an expert and qualified staff in industry. For this reason, inquiry of this subject is important.

\subsection{Objective of Research}

The objective of the study is to identify cooperation between business world and university and analyse the situation. To make recommendations to the university and business world in line with the results obtained.

\subsection{Research Method and Scope}

In this study, survey method has been used. Questionnaires have been analyzed by the means of SPSS24 package. The scope of the research is authorities working in companies in Baku.

\subsection{Findings of Research}

In reliability analysis, it is based upon the hypothesis that all questions in the survey measure the same feature. The low internal consistency coefficient of Cronbach Alpha may indicate that the questionnaire measures several characteristics together. Alpha value $(\alpha)$ obtained as a result of the test is accepted as a homogeneity symbol of the test. Cronbach Alpha coefficient is 0.70 for the general acceptance (Tavshancil, 2006: 29).

If $0,00 \leq \alpha<0,40$ scale is not reliable

If $0,40 \leq \alpha<0,60$ scale has low reliability

If $0,60 \leq \alpha<0,80$ scale is very reliable

If $0,80 \leq \alpha<1,00$ scale is highly reliable 
Reliability coefficient for needs analysis survey of enterprises applied in reliability analysis was found $\alpha=$ $0,729, \alpha=0,919, \alpha=0,852$ and $\alpha=0,778$. This "Cronbach Alpha" internal consistency coefficiency shows that the scale is highly reliable.

\subsubsection{Profile of Enterprises and Attendees}

Distribution of enterprises in the research by sector; 79 (72.5\%) of the enterprises are financial enterprises, 8 (7.3\%) are tourism enterprises, $3(2.8 \%)$ are educational enterprises, 2 (1.8\%) are health enterprises, 3 (2.8\%) are agricultural enterprises, $3(2.8 \%)$ are transportation enterprises, 4 (3.7\%) are industry enterprises, 5 (4.6\%) are commercial enterprises, 2 (1.8\%) are energy enterprises. If enterprises are examined according to their legal structure, 33 (30.3\%) of the enterprises are anonymous, 65 (62.4\%) are limited partnership and 8 (7.3) are other enterprises. The majority of the enterprises included in the research is observed to be a stock corporation. Most of the stock corporations comprise of limited companies, since they are more easily established than other companies. Therefore, when we look at the legal distribution of the enterprises within the scope of the research, it is natural that limited companies have a high rate like $65 \%$.

27 (24.8\%) of research attendees are finance directors, 14 (12.8\%) are business owners, 14 (12.8\%) are accountants, 8 (7.3\%) are accountant assistants, 8 (7.3\%) are directors, 8 (7.3\%) are director assistants, 7 (6.4\%) are financial analyst, 5 (4.6\%) are branch managers, 4 (3.7\%) are finance directors, 4 (3.7\%) are head experts, 2 (1.8\%) are small experts, $1(0.9 \%)$ is a consultant, $1(0.9 \%)$ is a financier, $1(0.9 \%)$ is a wage accountant, $1(0.9 \%)$ is a clerk, $1(0.9 \%)$ is a tax specialist, $1(0.9 \%)$ is a trainee, $1(0.9 \%)$ is an expert, $1(0.9 \%)$ is a planning worker. The fact that almost half of the survey attendees are accounting managers shows parallelism with the modulus subject of enterprise in the previous section.

When the education levels of the participants were examined, it was observed that high rate $(87 \%)$ of the participants in the management level of enterprises graduated from high schools and higher education institutions. $77(70.6 \%)$ of the attendees were graduated from bachelor, 29 (26.6\%) were master and 2 (1.8\%) were complete secondary and $1(0.9 \%)$ was incomplete secondary school graduates.

The other question addressed to the survey participants in work groups was if they were members of any vocational organization. While $29.4 \%$ (32) of the participants was a member of the vocational organizations, $70.6 \%$ (77) of them was not a member of the vocational organizations.

Information about how participants being a member of any vocational organizations in a rate of $32 \%$ follow the professional development shows that $80(73.4 \%)$ of them follow it from internet, 17 (15.6\%) from professional seminars and courses, 1 (0.9\%) from Trade Unions, 8
(7.2\%) from other sources.

\subsubsection{Features of Members of Profession/ Applicants}

In this section, the focus group and education level of profession holders working in the companies attended in the survey and profession candidates, relevant field and section in the companies, general features, personality traits, fundamental abilities and internship satisfaction level related to those candidates have been handled.

\subsubsection{Analysis of Accounting Department Personnel and Candidates}

Education level of accounting-finance staff currently employed by the enterprises including in the research is relative to the distribution of the school level (college excluded) of employees working in accounting and finance departments. Therefore, 87 (79.8\%) of employed accountants are bachelor's degree, 21 (19.3\%) are master's degree and $1(0.9 \%)$ is vocational higher school graduates.

The data on the education level requirement for participants and accordingly the personnel planned to be employed in accounting department of the enterprises has been presented. The education levels enterprises seek in accounting graduates are listed as follows: There are 105 (96.3\%) enterprises seeking accounting-finance graduate, 2 (1.8\%) seeking marketing graduate, 1 (0.9\%) seeking office administrator graduate.

According to the participants, department where accounting graduates can work: In line with the survey, there are 105 (96.3\%) enterprises thinking of employing accounting graduates in Accounting-finance department, 2 (1.8\%) enterprises considering employing them in Marketing department, 1 (0.9\%) desiring to see in Human Resources department, 1 (0.9\%) thinking of employing in Office administration department.

68 (62.4\%) enterprises desire to employ accounting graduates in Accounting department, 29 (26.6\%) in General accounting, 6 (5.5\%) in Cash management, 5 (4.6\%) in Cost accounting, and $1(0.9 \%)$ in other areas. According to these results, enterprises want to evaluate newly graduated accounting staff mostly in pre-accountancy, afterward in general accounting areas. When the participants were asked the reason for this, the answer was that the companies where they are employed give more importance to those two departments.

\subsubsection{Intern Acceptance and Satisfaction Cases}

Doing internship is very significant for Vocational Higher School and other vocational educational institution graduates in order to adapt their work life and get hands on practical training as well as theoretical training. Internship is a meeting point for both a student and an employer. Based on this, according to the answers of the question if they hire a student as an intern in their company, 102 (93.6\%) of the enterprises hire a student as an intern, while 5 (4.6\%) of them do not 
include trainee students.

The enterprises accepting interns choose them from the students currently studying at Vocational High Schools. The enterprises not accepting interns have explained this situation with two justifications based on their previous experience. Initially, those enterprises find internship period too short. Short duration causes inavailability of returning obtained information to the company and the enterprise sees this as a waste of resources. The second reason why they do not accept a trainee is that students cannot adapt work life.

\subsubsection{Expectations of Business World}

This chapter has viewed importance level of vocational lessons in accounting-finance training given by universities from the perspective of focus group in the study and the enterprises participated in the survey, the fields where employees are the least sufficient and which lessons should be taken in order to improve knowledge and skills of professional staff.

\subsubsection{Importance Level of Vocational Lessons}

Lessons which will meet with the competence requirements of staff to be employed in accounting-finance units have been listed and assessed from 1 to 5 by considering their importance level due to the companies. This assessment has been presented in Table 1.

Table 1. Importance order of courses taken by accounting profession candidates

\begin{tabular}{|l|c|c|c|c|c|c|}
\hline & $\mathbf{1}$ & $\mathbf{2}$ & $\mathbf{3}$ & $\mathbf{4}$ & $\mathbf{5}$ & Total \\
\hline $\begin{array}{l}\text { Pre-accountancy } \\
\text { (current account- stock } \\
\text { tracking-VAT) }\end{array}$ & 56.9 & 33 & 6.4 & & 96.3 \\
\hline General accounting & 54.1 & 43.1 & 0.9 & & & 98.2 \\
\hline Tax law and accounting & 21.1 & 65.1 & 11.9 & & & 98.2 \\
\hline $\begin{array}{l}\text { Computerized } \\
\text { accounting }\end{array}$ & 64.2 & 25.7 & 7.3 & & & 97.2 \\
\hline $\begin{array}{l}\text { Labour and social } \\
\text { security law }\end{array}$ & 11 & 51.4 & 22.9 & 2.8 & 10.1 & 98.2 \\
\hline Corporate accounting & 52.3 & 33 & 11.9 & & & 97.2 \\
\hline Cost accounting & 61.5 & 29.4 & 6.4 & & 97.2 \\
\hline $\begin{array}{l}\text { Financial statements } \\
\text { analysis }\end{array}$ & 52.3 & 36.7 & 6.4 & & & 95.4 \\
\hline Financial management & 31.2 & 48.6 & 14.7 & & 3.7 & 98.2 \\
\hline $\begin{array}{l}\text { Specialized (Bank } \\
\text {-Management-Foreign } \\
\text { Trade) Accounting }\end{array}$ & 42.2 & 32.1 & 20.2 & 0.9 & & 95.4 \\
\hline Auditing service & 45.9 & 33.9 & 17.4 & 0.9 & & 98.2 \\
\hline Statistics & 22.9 & 56 & 18.3 & 0.9 & & 98.2 \\
\hline
\end{tabular}

As seen from the table, competencies which should be possessed by the accounting staff who works and will work in your company have been identified as Very important 62 (56.9\%), Important 36 (33\%), Not important 7 (6.4\%) due to pre-accounting (Current
Account-Stock tracking-VAT) level.

As seen from the table, competencies which should be possessed by the accounting staff who works and will work in your company have been identifies as Very important 59 (54.1\%), Important 47 (43.1\%), Not important $1(0.9 \%)$ due to general accounting level.

As seen from the table, competencies which should be possessed by the accounting staff who works and will work in your company have been identifies as Very important 71 (65.1\%), Important 23 (21.1\%), Not important $13(11.9 \%)$ due to tax law and accounting level.

As seen from the table, competencies which should be possessed by the accounting staff who works and will work in your company have been identifies as Very important 70 (64.2\%), Important 28 (25.7\%), Unimportant 8 (7.3\%) due to computerized accounting level.

As seen from the table, competencies which should be possessed by the accounting staff who works and will work in your company have been identifies as important 56 (51.4\%), Not Important 25 (22.9\%), Very important 12 (11\%), No idea $11(10.1 \%)$ due to labour and social security law level.

As seen from the table, competencies which should be possessed by the accounting staff who works and will work in your company have been identifies as Very important 57 (52.3\%), Important 36 (33\%), Not important 13 (11.9\%) due to corporate accounting level.

As seen from the table, competencies which should be possessed by the accounting staff who works and will work in your company have been identifies as Very important 67 (61.5\%), Important 32 (29.4\%), Not important 7 (6.4\%) due to cost accounting level.

As seen from the table, competencies which should be possessed by the accounting staff who works and will work in your company have been identifies as Very important 57 (52.3\%), Important 40 (36.7\%), Not important 7 (6.4\%) due to financial statements analysis level.

As seen from the table, competencies which should be possessed by the accounting staff who works and will work in your company have been identifies as Important 53 (48.6\%), Very important 34 (31.2\%), Not important $16(14.7 \%)$, No idea $4(3.7 \%)$ due to financial management level.

As seen from the table, competencies which should be possessed by the accounting staff who works and will work in your company have been identifies as Very important 46 (42.2\%), Important 35 (32.1\%), Not important 22 (20.2\%), Not important at all $1(0.9 \%)$ due to specialized (Bank -Management-Foreign Trade) Accounting level.

As seen from the table, competencies which should be possessed by the accounting staff who works and will work in your company have been identifies as Very 
important 50 (45.9\%), Important 37 (33.9\%), Not important 19 (17.4\%), Not important at all 1 (0.9\%) due to finance analysis level.

For companies, which lessons will be more efficient and equipped for the accounting staff working and will be working in the company during their training have been listed below. While being listed, the companies have made their choices due to the lessons meeting with the needs of their own companies and which part their enterprises pay more attention. Aforesaid choices have been listed due to the importance level as follows:

1) Pre-accounting,

2) General accounting,

3) Computerized accounting,

4) Cost accounting,

5) Corporate accounting,

6) Accounting analysis,

7) Tax law and accounting,

8) Financial management,

9) Financial statements analysis,

10) Labour and Social Security Law,

11) Specialized accounting (Bank-ManagementForeign Trade),

12) Statistics.

As is seen, it is the most significant issue for the enterprises is pre-accounting lessons to be taken by the employees during their training who will be working in this enterprises.

Azerbaijan State University of Economics - UNEC Business School has been a full member of the US Business School Development Association (AACSB) since 2016 and is accredited by the Association of Certified Public Accountants (ACCA), according to information received from the Director of the UNEC Business School. won the right to acquire. UNEC Business School increased its national share in the 56th program in the 2014-2015 academic year from $43.5 \%$ to $73 \%$ in the 2018-2019 academic year. This shows that important attempts have been made to ensure that those who receive accounting education in Azerbaijan receive training in accordance with international certification programs. In addition, the University's English language programs are currently among the most sought after by applicants. The minimum passing score for admission to these programs at the undergraduate level is currently over 630. These training programs are accredited by reputable international organizations such as the Association of Certified Accountants (ACCA) and the Institute of Certified Financial Analysts (CFA), and graduates of these programs have many privileges to obtain the relevant certification of these organizations.

By the Ministry of Finance, ACCA Fundamental translates resources from F1 to F9 and ACCA Professional P1 to P, providing free of charge to both universities and other educational institutions.
"Financial Reporting” certificate programs are provided in Azerbaijan, Russian and English by the Ministry of Finance, the Finance Science-Education Center and other training centers that have received authorization certificates.

\section{Conclusions}

The accounting profession is among the favorite professions of the business world. As a result of the changes and new developments in the business world, the qualifications needed in the accounting staff who will perform this favorite profession are becoming more important every day. Meeting the expectations of the business world depends on the communication between universities and employers that raise resources for the workforce. When the findings of the study, which was conducted to determine the expectations of the business world to contribute to the realization of this communication, were evaluated, the following results were reached.

It was observed that the majority of enterprises were stock corporations. Therefore, when we look at legal distribution of enterprises within the scope of the research, it is natural that Limited companies have a high rate like $65 \% .70 .6 \%$ of attendees had bachelor education. The next place was master education with $26.6 \%$. $73.4 \%$ of attendees follow the developments from internet. It is more than other sources. The meeting frequency of accounting department is usually once in 15 days or once in a month. Education level employers seek in accounting graduates is generally accounting-finance. The department that accounting-finance graduates can work is usually Accounting-finance department. According to the trainee acceptance situation of the enterprise, $93 \%$ of the enterprises take students as a trainee studying at accounting program. According to the satisfaction situation of the trainee student, $58.7 \%$ of the enterprises are satisfied with the knowledge background of trainee students.

As a result of the evaluation of the professional courses taken by the new graduates / interns during their accounting education according to the importance degree by the members of the profession, respectively, Pre-Accounting, General Accounting, Computerized Accounting, Cost Accounting, Corporate Accounting, Accounting Auditing, Tax Law and Accounting, Financial Management, Financial Statement Analysis, Business and Social Security Law, Specialized Accounting (Bank-Management-Foreign Trade) and Statistics. In line with this information, they found the qualifications gained by the professional members during the training of accounting staff who graduated from the accounting program sufficient. However, it is thought that they aim to gain the expected qualifications through in-service training. 


\section{REFERENCES}

[1] Albrecht, W \& Sack, R 2000, Muhasebe eğitimi: Tehlikeli bir gelecekle kursu belirleme, Amerikan Muhasebe Birliği Sarasota, FL. (İngilizce)

[2] Alkan, G. (2015). İşletmelerin Önlisans Muhasebe Eğitiminden Beklentileri: İzmir'de Bir Araştırma. Muhasebe Bilim Dünyası Dergisi, 17(1), 137-158.

[3] Andersen, A 1989, Eğitime bakış açıları: Muhasebe mesleğinde başarı için yetenekler, New York. (İngilizce)

[4] Apostolou, B., Dorminey, J. W., Hassell, J. M., \& Hickey, A. (2019). Accounting education literature review (2018). Journal of Accounting Education. doi:10.1016/j.jaccedu.2019.02.001

[5] Awayiga, JY, Onumah, JM \& Tsamenyi, M 2010, 'Muhasebe mezunlarının bilgi ve beceri gelişimi: Mezunların ve ganadaki ișverenlerin algıları', Muhasebe Eğitimi: Uluslararası bir dergi, cilt. 19, hayır. 1-2, sayfa 139-58. (İngilizce)

[6] Ballantine, J \& Larres, P 2007, 'İşbirlikli öğrenme: Öğrencilerin genel becerilerini geliştirmek için bir pedagoji?', Eğitim Eğitimi, cilt. 49, hayır. 2, sayfa 126-37. (İngilizce)

[7] Ballantine, J \& Larres, P 2009, 'Muhasebe,' mesleki muhasebe eğitimi ve öğretimi ile başarılı bir şekilde etkileşime geçmek için kişilerarası ve iletişim becerilerini geliștirmek için bir model olarak işbirlikli öğrenmeye ilişkin algıların altını çiziyor ', Muhasebe Eğitimi: Uluslararası bir dergi, cilt. 18, hayır. 4-5, sayfa 387-402. (İngilizce)

[8] Farrell, B \& Farrell, H 2008, 'Bir muhasebe müfredatında işbirlikli öğrenmeyle öğrenci memnuniyeti', Üniversite Ögretme ve Öğrenme Uygulaması Dergisi, vol. 5, hayır. 2, sayfa 39-54. (İngilizce)

[9] Fortin, A \& Legault, M 2010, 'Genel Yeterliliklerin Geliştirilmesi: Karışık bir öğretim yaklaşımının öğrencilerin algıları üzerindeki etkisi', Muhasebe Eğitimi: Uluslararası bir dergi, cilt. 19, hayır. 1, sayfa 93 - 122. (İngilizce)

[10] Hancock, P, Howieson, B, Kavanagh, M, Kent, J, Tempone, Ben, Segal, N \& Freeman, M 2009, 'Avustralya'da muhasebe eğitiminin geleceğinde bazı kilit paydaşların rolleri', Avustralya Muhasebe İncelemesi, hac. 19, hayır. 3, sayfa 249-60. (İngilizce)

[11] Hodson, D 1988, 'Fen ve Fen Öğretiminde Deneyler', Eğitim felsefesi ve teorisi, vol. 20, hayır. 2, sayfa 53-66. (İngilizce)

[12] Howieson, B 2003, 'Yeni Binyılda Muhasebe Uygulamaları: Muhasebe eğitimi bu zorlukla başa çıkmaya hazır mı?', The British Accounting Review, vol. 35, hayır. 2, sayfa 69-103. (İngilizce)

[13] Jackling, B \& De Lange, P 2009, 'Muhasebe mezunlarının becerileri' işverenlerin beklentilerini karșılıyor mu? Bir yakınsama veya uzaklaşma meselesi ', Muhasebe eğitimi, cilt. 18, hayır. 4, sayfa 369-85. (İngilizce)

[14] Jackling, B \& Watty, K 2010, 'Genel Beceriler', Muhasebe Eğitimi: Uluslararası Bir Dergi, vol. 19, hayır. 1-2, sayfa

\section{1-3. (İngilizce)}

[15] Jackling, B 2005, 'Öğrenme bağlamına ilișkin algılar ve öğrenme yaklaşımları: Muhasebede kaliteli öğrenme çıktılarının etkileri', Muhasebe eğitimi, vol. 14, hayır. 3, sayfa 271-91. (İngilizce)

[16] Johnson, D \& Johnson, R 1994, Birlikte ve yalnız öğrenme: İşbirlikçi, rekabetçi ve bireysel öğrenme, 4. Bask1, Dizi Boston:, Allyn ve Bacon. (İnglizce)

[17] Jones, A 2010, " Muhasebede genel özellikler: Disiplin bağlamının önemi ',' Muhasebe Eğitimi Uluslararası Journa, vol. 19, hayır. 1, sayfa 2-21. (İngilizce)

[18] Jones, G \& Abraham, A 2008, 'Muhasebecileri bugünün küresel iş ortamına hazırlamak: Duygusal zekanın muhasebe eğitimindeki rolü', Ticaret Fakültesi-Makaleler, s. 482. (İngilizce)

[19] Joyce, B, Weil, M \& Calhoun, E (eds) 2009, Öğretim modelleri, 8. edn, Pearson Education, Inc, Boston. (İngilizce)

[20] Kavanagh, M \& Drennan, L 2007, 'Lisansüstü nitelikler ve beceriler: Malları veren muhasebe akademisyeni olarak miyı?'(İngilizce)

[21] Kavanagh, M \& Drennan, L 2008, 'Muhasebe mezunu hangi becerileri ve özellikleri gerektirir? Öğrenci algilarından ve işveren beklentilerinden elde edilen kanıtlar ', Avustralya Muhasebe ve Finans Birliği ve Yeni Zelanda Konferans1, Avustralya, Adelaide'da sunulan bildiri. (İngilizce)

[22] Kavanagh, M \& Drennan, L 2008, 'Muhasebe mezunu hangi becerileri ve özellikleri gerektirir? Öğrenci algılarından ve işveren beklentilerinden elde edilen kanıtlar ', Avustralya Muhasebe ve Finans Birliği ve Yeni Zelanda Konferans1, Avustralya, Adelaide'da sunulan bildiri. (İngilizce)

[23] Khayati, A., \& Ariail, D. L. (2020). Business students' perceptions of faculty attributes: a two-country cross-cultural comparison. Accounting Education, 29(2), 153-176.

[24] Mohamed, E \& Lashine, S 2003, 'Muhasebe bilgi ve becerileri ve küresel bir iş ortamının zorlukları', Managerial Finance, vol. 29, hayır. 7, sayfa 3-16. (İngilizce)

[25] Mohidin, R, Jaidi, J, Sang, LT ve Osman, Z 2009, 'Etkili öğretim yöntemleri ve öğretim görevlisi, universite malaysia sabah (ss)' daki muhasebe öğrencilerine yönelik bir çalışma ', Avrupa Sosyal Bilimler Dergisi, vol. 8, hayır. 1. (İngilizce)

[26] Muhasebe Eğitimi Değişim Komisyonu 1990b, 'Muhasebeciler için eğitimin amaçları: Bir numaralı pozisyon ifadesi', Muhasebe Eğitiminde Meseleler, vol. 5, hayır. 2, s. 30

[27] 27. 27. Rebele, JE 1985, 'Muhasebe öğrencilerinin kamu muhasebesinde iletişim becerilerinin önemine ilişkin algılarının incelenmesi', Muhasebe Eğitiminde Konular, no. 3, s. 41. (İngilizce)

[28] Stoner, G \& Milner, M 2010, 'Muhasebe Derecesinde Genel Kullanılabilirlik Becerilerinin Yerine Getirilmesi: Gelişme ve Engeller', Muhasebe Eğitimi: Uluslararası Bir Dergi, Cilt. 19, hayır. 1, sayfa 1-16. (İngilizce) 
[29] Tugay, O., \& Ömürbek, V. (2014). Meslek Yüksekokullarında Verilen Muhasebe Derslerinin Uygulamada Kullanılma Düzeyi ve Yeterliliği Üzerine Bir Araştırma. Niğde Üniversitesi İktisadi İdari Bilimler Fakültesi Dergisi, 7(3), 53-74.

[30] Wells, P. K. (2018). How well do our introductory accounting text books reflect current accounting practice? Journal of Accounting Education, 42, 40-48.

[31] Yıldız, G. (2017). Muhasebe Meslek Mensuplarının Meslek Yüksekokulu Muhasebe Programı Öğrencilerinden Beklentileri: Kayseri İlinde BirAraştırma. Muhasebe ve Finansman Dergisi(73), 169-184.

[32] Yürekli, E., \& Gönen, S. (2015). Muhasebe Meslek Mensuplarının Nitelikli Meslek Mensubu Yetiştirilmesine Yönelik Önlisans Programlarından Beklentileri. Kafkas Üniversitesi İktisadi İdari Bilimler Fakültesi Dergisi, 6(10), 301-316.

[33] Zakaria, E \& İksan, Z 2007, 'Fen ve matematik eğitiminde işbirliğine dayalı öğrenmeyi teşvik etmek: Malezya perspektifi', Avrasya Matematik Dergisi, Fen ve Teknoloji Eğitimi, cilt. 3, hayır. 1, sayfa 35-9. (İngilizce)

[34] Zraa Wahida, (2011) Yeni Binyıl Cambridge İşletme ve Ekonomi Konferansi'nda (CBEC) muhasebe eğitimi, Cambridge Üniversitesi, İngiltere. (İngilizce)

[35] Accounting Tools Accounting CPE Courses \& Books, https://www.accountingtools.com/articles/2017/5/15/accru als-concept

[36] Accounting Tools Accounting CPE Courses \& Books, https://www.accountingtools.com/articles/2017/5/14/the-c onservatism-principle

[37] Consistency concept

[38] Accounting Tools Accounting CPE Courses \& Books, https://www.accountingtools.com/articles/2017/5/14/the-ec onomic-entity-principle

[39] Accounting Tools Accounting CPE Courses \& Books, https://www.accountingtools.com/articles/2017/5/14/the-g oing-concern-principle
[40] Accounting Tools Accounting CPE Courses \& Books, https://www.accountingtools.com/articles/2017/5/14/the-m atching-principle

[41] Accounting Tools Accounting CPE Courses \& Books, https://www.accountingtools.com/articles/2017/5/14/the-m ateriality-principle

[42] Accounting Concepts, Principles and Basic Terms, https://www.mbacrystalball.com/blog/accounting/

[43] The Role of Accounting, https://saylordotorg.github.io/text_exploring-business-v2.0 /s16-01-the-role-of-accounting.html

[44] Accounting Tools Accounting CPE Courses \& Books, https://www.accountingtools.com/articles/2017/5/10/finan cial-accounting

[45] Accounting Tools Accounting CPE Courses \& Books, https://www.accountingtools.com/articles/what-is-public-a ccounting.html

[46] Accounting Tools Accounting CPE Courses \& Books, https://www.accountingtools.com/articles/governmental-ac counting.html

[47] Accounting Tools Accounting CPE Courses \& Books, https://www.accountingtools.com/articles/forensic-account ing-overview.html

[48] Accounting Tools Accounting CPE Courses \& Books, https://www.accountingtools.com/articles/2017/5/8/manag ement-accounting

[49] Accounting Tools Accounting CPE Courses \& Books, https://www.accountingtools.com/articles/tax-accounting.h tml

[50] Accounting Tools Accounting CPE Courses \& Books, https://www.accountingtools.com/articles/2017/9/27/intern al-audit

[51] Accounting Tools Accounting CPE Courses \& Books, https://pdf.wondershare.com/accounting/accounting-infor mation-system.html 